$$
\begin{gathered}
\text { Universidade de Brasília - UnB } \\
\text { Instituto de Artes - IdA } \\
\text { Departamento de Artes Visuais - Vis }
\end{gathered}
$$

A importância das Histórias em Quadrinhos para a Educação

\author{
Mauro César Bandeira de Oliveira
}

Brasília, Dezembro de 2007 


\author{
Universidade de Brasília - UnB \\ Instituto de Artes - IdA \\ Departamento de Artes Visuais - Vis
}

\title{
A importância das Histórias em Quadrinhos para a Educação
}

\section{Mauro César Bandeira de Oliveira}

Trabalho de conclusão do curso de Artes Plásticas, Habilitação em Licenciatura, do Departamento de Artes Visuais do Instituto de Artes da Universidade de Brasília. Orientadora: Prof ${ }^{a}$ Cristina Azra

Barrenechea 


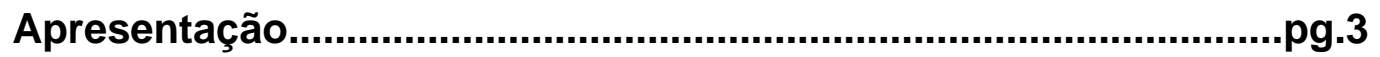

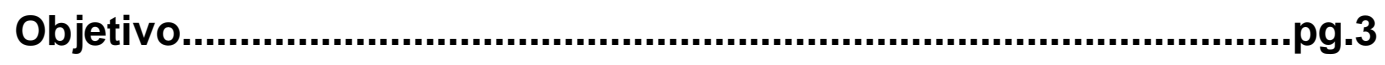

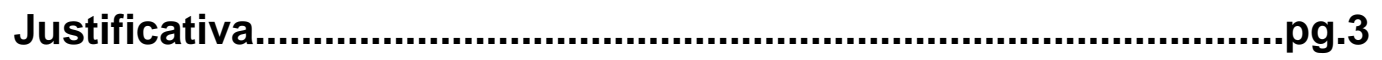

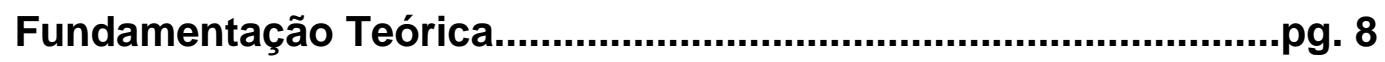

Proposta de Criação de uma Oficina em

Arte Seqüencial na Universidade...................................................pg.20

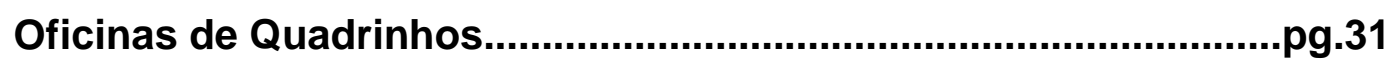

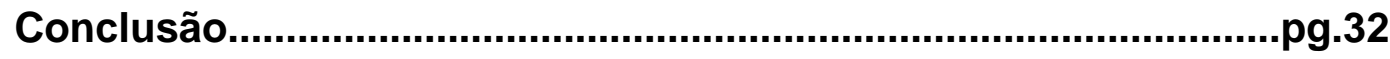

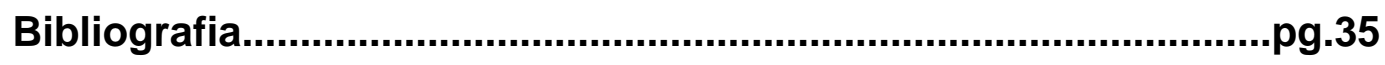

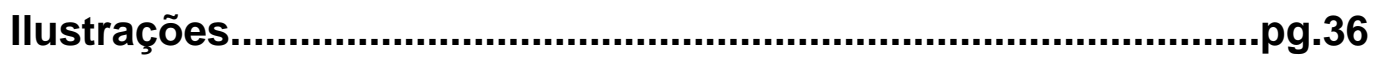




\section{Apresentação}

O presente estudo discute a importância das histórias em quadrinhos para a educação e propõe a discussão a respeito do desenvolvimento de uma disciplina de Criação em Arte Seqüencial (história em quadrinhos, tiras, charges, cartoons, vinhetas) no currículo dos Cursos de graduação em Artes Visuais, Design e Comunicação.

\section{Objetivo}

Este projeto busca refletir sobre a importância do uso dos quadrinhos na educação, em suas diferentes possibilidades pedagógicas.

Esse projeto explora as e potenciais para que se abra um espaço na universidade para academia debater criticamente a necessidade da criação de disciplinas voltadas para a formação em Arte Seqüencial.

\section{Justificativa}

A escolha do tema dessa monografia se deve ao fato de que eu sempre gostei de ler histórias em quadrinhos. Eu acredito que, assim como eu, as crianças e jovens gostariam também de aprender mais sobre técnicas de como produzir suas próprias histórias em quadrinhos.

Penso sobre muitas possibilidades para ver as Histórias em Quadrinhos $\mathrm{HQ}$ - como uma área de grande importância para a formação em todos os níveis do ensino: fundamental, médio e superior. Sou muito otimista em tudo que pretendo projetar e coloco meus sonhos como metas para realizá-los no futuro. Sei que há muitas burocracias e falta de vontade em grande parte das pessoas que só acreditam na realização financeira de qualquer empreendimento, e vivemos em um mundo de aparências e de status. 
Como todos sabem as histórias em quadrinhos servem para diversão e entretenimento, mas seu uso ainda é reduzido como veículo de pesquisa e ensino.

Na educação fundamental e média, os quadrinhos ainda não são incluídos como conteúdo programático nos currículos escolares, e nem mesmo como metodologia didática para ensinar outras disciplinas tais como língua portuguesa, matemática, geografia, etc.

Observa-se que nas faixas etárias do ensino fundamental e médio há grande consumo de quadrinhos pelo público estudantil. Os quadrinhos ajudam as crianças e jovens a consolidar seus hábitos de leitura e compreensão de idéias, sem falar do potencial dos quadrinhos em trabalhar conteúdos curriculares por causa da sua grande aceitação.

Se nós podemos observar que as crianças e os jovens têm hábitos bastante arraigados de leitura de histórias em quadrinhos, pode-se dizer que este interesse está sendo pouco aproveitado pela escola.

A arte seqüencial ainda não está presente na sala de aula, como uma linguagem que ajude a integrar os conteúdos curriculares com a cultura, a linguagem e o interesse das crianças.

As experiências que se observam aqui e ali são ainda muito tímidas em contraposição com a grande necessidade e com o grande potencial desta linguagem que tem uma audiência cativa entre os mais jovens.

Nas escolas, alguns professores de língua Portuguesa utilizam quadrinhos para trabalhar diferentes conteúdos e estratégias didáticas. Quando isto acontece, o interesse pelo texto apoiado por imagens da arte seqüencial é comum entre os estudantes de diferentes faixas etárias e culturas.

Devido a uma série de fatores favoráveis ao uso didático das histórias em quadrinhos na sala de aula, notamos uma grande necessidade de integrar esta 
linguagem como conteúdo e como método didático nas escolas de nível fundamental.

Já nas escolas de nível médio e superior há uma grande demanda por cursos e disciplinas em Criação de Artes Seqüenciais que venham a promover a formação de quadrinhistas, cartunistas, e chargistas para abastecer uma crescente demanda por profissionais nessa área. Nenhuma dessas áreas está sendo suprida de acordo com um mercado de trabalho potencial e com as enormes possibilidades de formação de criadores em Arte Seqüencial em nossa nação.

Aparentemente, a linguagem da Arte Seqüencial não encontra o amplo reconhecimento nos cursos superiores de Artes, Comunicação ou Design, pois não encontramos com freqüência disciplinas obrigatórias ou optativas que se dediquem à formação de habilidades na criação e produção em "arte seqüencial". Quando muito se observam iniciativas isoladas no currículo acadêmico, ou em projetos de extensão, e mesmo assim com um enfoque principalmente teórico.

Assim como a Moda, as Artes Seqüenciais ainda não conquistaram seu lugar nos currículos da graduação e nem nos currículos dos cursos técnicos profissionalizantes.

No entanto, nós podemos afirmar que as histórias em quadrinhos gozam de uma apreciação do público. Mas apesar de se constituir uma linguagem muito popular, esta arte parece marginal quando comparada com o apoio institucional que as outras Artes recebem.

Nós sabemos que as histórias em quadrinhos brasileiros não são reconhecidas como literatura, mas nesse caso vejo que ocorre uma grande injustiça em não considerar o trabalho dos nossos desenhistas como obras literárias. 
Notamos uma necessidade de valorizar as Artes Seqüenciais promovendo esta linguagem ao status das demais Artes. Atualmente os quadrinhos são considerados a nona arte, sem, no entanto desfrutar do status das outras oito linguagens artísticas.

Em um momento futuro eu pretendo desenvolver uma oficina para o ensino de criação de história em quadrinhos. Seu planejamento ainda está em andamento. O planejamento da oficina como um todo, eu não fecharei favorecendo assim que novos pesquisadores acrescentem mais idéias para dessa forma melhorarem a idéia inicial que é ainda um embrião.

O projeto universidade dos quadrinhos é muito utópico, mas é preciso encará-lo com seriedade às vezes a loucura é necessária para algo ir para frente, as pessoas normais são muito lineares não vão além do raciocínio lógico e formalista, o que pretendermos mesmo ir contra essas falsas regras morais imposta pelo capitalismo. Uma das leis principais do capitalismo é a que sem dinheiro a pessoa não é ninguém, para ir contra esse princípio satânico, nós vamos criar uma universidade sem dinheiro nenhum, o que vamos fazer é mostrar talentos dessas pessoas que não tiveram a oportunidade de entrar em uma universidade "normal".

Todo sistema educacional é direcionado para conceder oportunidades para os mais ricos e os mais bem preparados e conseqüentemente eliminar os que o estão a margem desse sistema. Essa lógica educacional é toda pautada no sistema, para isso ser quebrado é preciso que as pessoas se solidarizem com essa causa, devemos aceitam tudo que vem para nos excluir, para tirar nossas oportunidades, esse trabalho está sendo duramente criticado por alguns alunos alienados e que estão inseridos parcialmente, porque as artes não recebem investimento por parte do governo por que eles não vêem interesse no seu ensino.

Os artistas devem ter consciência de sua luta solitária contra todos os preconceitos. Esse sistema de divisão de classes sociais nos considera incapazes de realizar qualquer projeto, por isso vamos nos comprometer a fazê-lo sem ajuda 
de ninguém não precisamos de comentários por parte de ninguém, apenas vamos resgatar as pessoas através da Arte seqüencial. Não estamos preocupados com que os outros vão falar da gente, pois queremos ser independentes desse sistema educacional antiquado que nos critica, não queremos saber de competições tolas e críticas infundadas e por isso vamos em frente com nosso projeto.

As histórias em quadrinhos têm um poder incrível de passar mensagens sobre acontecimentos complexos e complicados. Não é à toa que os cartunistas a utilizem para descrever fatos políticos apenas com um quadro. Digamos que alguém não entenda nada sobre o que está acontecendo no mundo e de repente vê uma charge de um político desenhada e de repente parece que, como mágica, entende rapidamente.

\section{Fundamentação Teórica}

O nosso sistema educacional brasileiro precisa criar um sistema de aprendizagem mais moderno e inclusivo. Por isso, a utilização das histórias em quadrinhos pode ser considerada também como meio de educação de adultos que estão sendo alfabetizados.

O uso da imagem associada ao texto pode facilitar e muito o aprendizado por que as pessoas não precisam saber ler para entender o que um desenho quer dizer, e ao mesmo tempo elas começam a querer aprender a ler.

A educação no Brasil ainda é um privilégio de poucos, e as nações emergentes como a Coréia do Sul e o Chile estão investindo muito em educação e já estão tendo retorno por que esses paises estão em constante desenvolvimento tecnológico.

O Brasil não pode perder essa chance de tornar um país com altas taxas educacionais, e precisará do apoio de todos recursos didáticos disponíveis, temos 
que utilizar mais os meios de comunicação e as diversas linguagens, principalmente as histórias em quadrinhos como meio de alfabetizar a população.

As idéias desse projeto buscam mostrar a importância dos quadrinhos para a educação, elas precisam ser bem claras para que todos entendam a importância das histórias em quadrinhos para a Universidade, existem muitas monografias falando sobre esse mesmo tema relacionado a histórias em quadrinhos na Educação.

Existem poucos livros nas bibliotecas para pesquisar sobre "Arte seqüencial" mas podemos encontrar alguns artigos científicos na Internet sobre este tema.

A linguagem dos quadrinhos como meio de expressão dos alunos no processo educacional ainda é muito pouco utilizado. Esta poderia ser uma forma de se trabalhar a escrita das crianças que estão aprendendo não só a ler, mas também a escrever.

No curso de Licenciatura em Artes Visuais nós não temos uma disciplina chamada "Arte Seqüencial". Ela poderia nos ajudar a desenvolver técnicas de criação em arte seqüencial, e também métodos didáticos para usá-los na educação. O próprio Will Eisner já ministrou essa disciplina na faculdade de Artes em Nova York. No Japão a profissão de quadrinhista de mangá é já tradição porque naquele país há uma larga impressão de histórias em quadrinhos.

Os Departamentos de Artes das Universidades deveriam ter uma disciplina de Arte seqüencial prática e uma linha de impressão para os trabalhos já concluídos, por que há um grande interesse de vários alunos universitários de realizar trabalhos na linguagem dos quadrinhos.

O sucesso das histórias em quadrinhos japonesas demonstra que a influência do Mangá é tão forte a ponto até de influenciar a língua de um país tão poderoso como os Estados Unidos. Algumas palavras japonesas foram 
incorporadas à língua inglesa por meio do Mangá sendo que muitos aspectos da cultura japonesa são conhecidos por meio de sua leitura.

É possível utilizar as histórias em quadrinhos como meio de alfabetização e confecção de livros didáticos de idiomas, podemos utilizá-las para facilitar a memorização porque, segundo algumas pesquisas o nosso cérebro retém mais informações que associam imagens e emoções.

O uso mais intenso das histórias em quadrinhos na Universidade vai promover uma interdisciplinaridade em diversas áreas que até então não estavam interligadas.

A utilização das histórias em quadrinhos como meio de interligar as áreas da academia entre si e com a sociedade tornará a universidade mais democrática e mais aberta às novas idéias. Se cada departamento da universidade tivesse seus próprios quadrinhistas para colocarem no papel, em desenhos e textos, as teorias e conceitos de forma mais acessível, saberíamos com mais facilidade o que os cursos estão propondo para a sociedade e quais são as idéias que estão sendo discutidas nas áreas acadêmicas.

Sabemos que existe um certo preconceito em relação aos quadrinhos, mas não existe comprovação científica que diga que os quadrinhos impeçam os jovens de ler outros livros. Ao contrário do que se pensa, muitos adultos se interessaram em ler e escrever quando crianças justamente por causa dos desenhos dos quadrinhos. Vamos acrescentar uma citação do livro de Will Eisner:

"Nos tempos modernos, a tira diária de jornal e, mais recentemente, a revista de quadrinhos constituem o principal veículo da Arte seqüencial. Na medida em que se tornou mais evidente o potencial desta forma, foi introduzida uma melhor qualidade e uma produção mais cara. Isso, por sua vez, resultou em publicações vistosas, em cores, que atraem um público mais refinado, ao mesmo tempo em que as revistas de quadrinhos em preto-e-branco impressas em papel de boa qualidade também encontravam a sua clientela". (EISNER, 1977) 
A linguagem das histórias em quadrinhos continua a ganhar força como forma válida de leitura. As primeiras revistas de quadrinhos apareceram por volta de 1934. Elas geralmente continham uma coleção aleatória de obras curtas. Quando se examina uma obra em quadrinhos como um todo, a disposição dos seus elementos específicos assume a característica de uma linguagem. O vocabulário da Arte Seqüencial tem se desenvolvido continuadamente nos Estados Unidos. Desde a primeira aparição dos quadrinhos na imprensa diária, na virada do século, essa forma popular de leitura encontrou um público amplo e, em particular, passou a fazer parte da dieta literária inicial da maioria dos jovens. As histórias em quadrinhos comunicam numa "linguagem" que se vale da experiência visual comum ao criador e ao público. Pode-se esperar dos leitores modernos uma compreensão fácil da mistura imagem-palavra e da tradicional decodificação de texto. A história em quadrinhos pode ser chamada "leitura" num sentido mais amplo que o comumente aplicado ao termo. A aprendizagem da leitura tem se apoiado fortemente nos quadrinhos. Tom Wolf, escrevendo na Harvard Educational Review (agosto de 1977) comenta:

"Durante os últimos cem anos, o tema da leitura tem sido diretamente vinculado ao conceito de alfabetização;....aprender a ler...tem significado aprender a ler palavras...Mas...gradualmente a leitura foi se tornando objeto de um exame mais detalhado. Pesquisas recentes mostram que a leitura de palavras é apenas um subconjunto de uma atividade humana mais geral, que inclui a decodificação de símbolos, a integração e a organização de informações...Na verdade, pode-se pensar na leitura - no sentido mais geral - como uma forma de atividade de percepção. A leitura de palavras é uma manifestação dessa atividade; mas existem muitas outras leituras - de figuras, mapas, diagramas, circuitos, notas musicais..." (WOLF, 1977).

Os quadrinhos podem ajudar na percepção de idéias com isso melhorando a compreensão, uma idéia posta no papel pode ser desenvolvida não apenas com a escrita se ela tiver imagens e uma história animada. 
O futuro da educação brasileira precisa ser encarado com seriedade e a produção de histórias em quadrinhos da Universidade de Brasília servirá para empregar muitos ilustradores que poderão se inscrever para elaboração de histórias e ilustrações para livros e teses.

A Universidade deve olhar para frente e ter como meta a inclusão maior da sociedade. Para esse processo se efetivar os próprios alunos precisam mostrar seus talentos escondidos e mostrar para sociedade que estamos dispostos a vencer desafios nesse milênio.

Seria possível criar um Centro de excelência de Arte seqüencial? Essa é pergunta. Há uma necessidade agora para sua criação, essas perguntas são difíceis de serem respondidas, mas se observarmos a maioria dos países mais ricos do mundo, os E.U.A e Japão são os maiores produtores de histórias em quadrinhos da atualidade. Os quadrinhos que são produzidos naqueles países ajudam a divulgar a cultura e os interesses de cada país. Vejo que há um incentivo por parte desses países de manterem uma ampla divulgação de suas histórias em quadrinhos e seus produtos licenciados, e desenhos animados.

As histórias em quadrinhos são manifestações culturais desses países e com certeza influenciam mais a faixa etária mais jovem. Não é por acaso por que nessas histórias são reforçados valores culturais dessas duas sociedades e outros estereótipos como, por exemplo, o da mulher retratada nas histórias em quadrinhos, como no livro da professora Selma."Mulher ao Quadrado":

"Elas são muitas, mas são como cópias de um só original, sambas de uma nota só. Mudam os nomes, as roupas, os cenários, mas no fundo, ou melhor, no interior de seus gestos, maneiras e falas, ou silêncios, deparamos com personagens re-elaboradas com base naquelas já existentes na literatura infantil, na mitologia, nos contos, enfim, nas narrativas que descrevem as mulheres como sombra de algum herói masculino". (OLIVEIRA, 2007) 
Ao ler o livro de Selma Oliveira, podemos observar que os estereótipos são um ponto a ser questionado nos valores que são veiculados nas histórias em quadrinhos: "Eva, aquela que não foi criada para si, mas para ser companhia de Adão. Maria, mãe e virgem santificada. Afrodite, deusa fútil da beleza e do amor. $A$ Pequena Sereia, que renunciou a seu reino pelo amor devotado a um mortal. A Bela Adormecida, cuja libertação dependeu do beijo de um príncipe. São inúmeras as histórias, mas todas parecem terminar sob tutela masculina" (OLIVEIRA, 2007)

Poderiam ser criados quadrinhos inovadores evitando explorar os estereótipos, e mudar um pouco de foco fazendo histórias em quadrinhos com temas de suma importância para a sociedade de um modo geral e fazer do quadrinho um instrumento mais coerente para os nossos dias.

É necessário passar mensagens positivas para a juventude não explorar apenas o lado cômico dos quadrinhos, mas propor idéias inovadoras por meio dessa linguagem. Nós poderíamos fazer histórias em quadrinhos enfatizando a importância da cultura brasileira para o mundo. Poderíamos fazer histórias falando sobre temas mais nobres.

As histórias em quadrinhos são um meio muito eficiente de propagação de idéias e existem uma quantidade muito grande de estilos e de artistas nos mais diversos países, mas muitas dessas histórias não são conhecidas aqui no Brasil. Poderia haver um intercâmbio maior entre os criadores de diferentes os países que produzem quadrinhos e que são desconhecidos pelo público brasileiro. Se houvesse um diálogo maior entre os quadrinhistas de diferentes países, poderia haver um maior acesso a essas obras e uma maior distribuição em todo o mundo.

Conseqüentemente teremos mais respeito pela sociedade se ela utilizar os quadrinhos para falar sobre a importância das pesquisas que são desenvolvidas na Universidade, isso tudo baseado nessa citação de Will Eisner.

"Na arena dos visuais de instrução - ou da aplicação da arte seqüencial ao ensino de algo especifico - , as limitações que afligem os quadrinhos destinados 
puramente ao entretenimento são menos atenuantes. Há duas formas de quadrinhos de instrução, os quadrinhos 'técnicos" e os "condicionadores de atitudes". (EISNER, 1977).

Existem quadrinhos puramente técnicos, nos quais o procedimento a ser aprendido é mostrado do ponto de vista do leitor. Eles dão instruções sobre execuções de tarefas geralmente associadas à montagem e ao concerto de aparelhos e são muito mais eficazes do que os manuais de instruções, ou os livros instrutivos que têm apenas texto.

"O desempenho dessas tarefas é, em si, de natureza seqüencial, e o sucesso dessa forma de arte como ferramenta de ensino está no fato de que o leitor pode facilmente estabelecer uma relação com a experiência demonstrada. Por exemplo, melhor maneira de expor um procedimento é fazê-lo a partir da perspectiva do leitor. A disposição dos quadrinhos, a posição do texto explanatório na página - tudo é calculado de modo a envolver o leitor." (EISNER, 1977)

O impacto dos desenhos animados e das histórias em quadrinhos é mais influente do que se pode pensar, existe uma série de fatos que levam as pessoas se identificarem com essas linguagens. Por exemplo, "Os Simpsons" é um desenho animado que ilustra bem esse fenômeno, na arte seqüencial há muitas tiras, cartoons e charges que são manifestações culturais contemporâneas e absorveram muito do que vivemos atualmente. "Os Simpsons", apesar de ser um desenho animado foi criado por um cartunista e mostra uma analogia com os quadrinhos. 
Figura 1

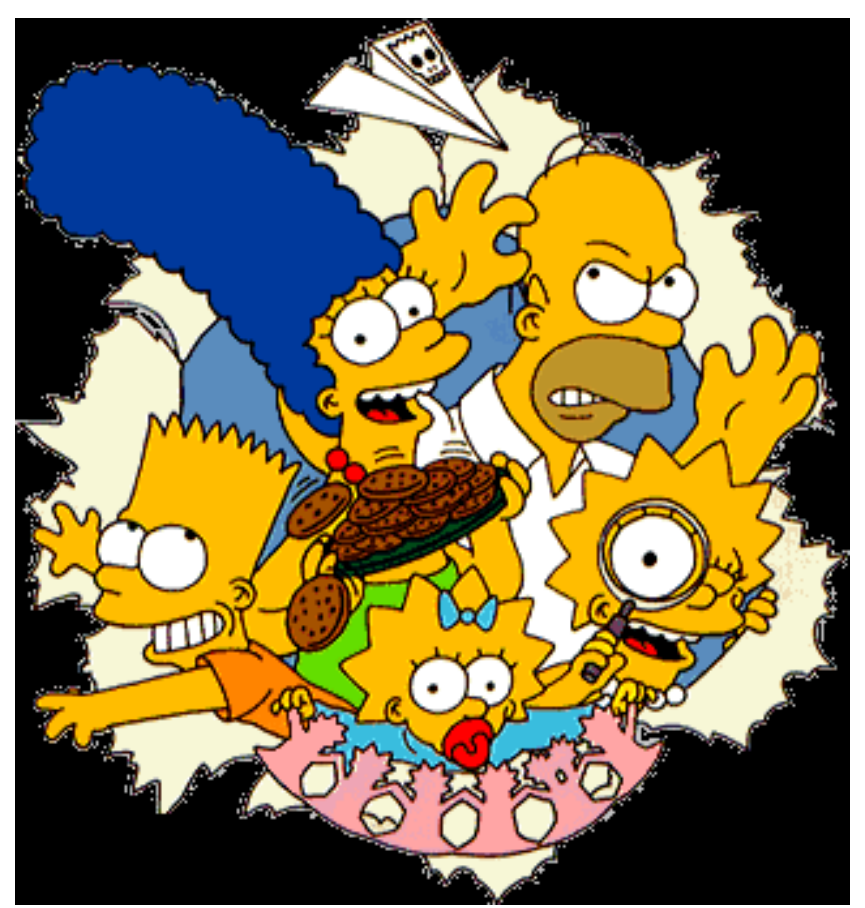

Figura 2

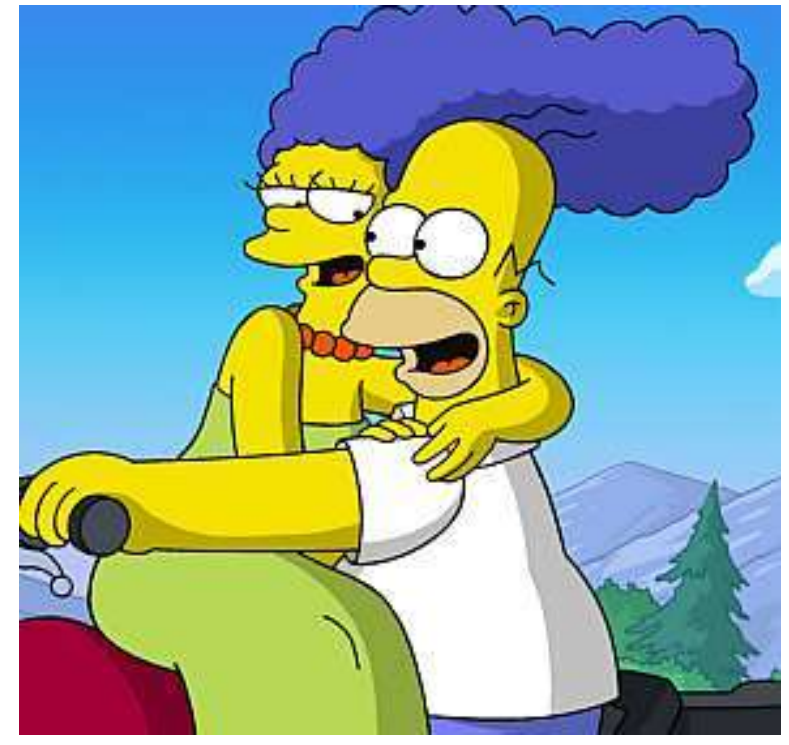

"Os Simpsons chega à maioridade embalado por uma série de paradoxos. Criada em 1987 em um formato associado ao público infantil, com o pré adolescente Bart como primeiro protagonista, a série foi fundamental para o reconhecimento do desenho animado como um entretenimento adulto, ao levar o patriarca Homer para o centro de holofotes após um par de anos no ar. Assim, 
inspirou uma tendência de animações, séries e filmes sobre famílias disfuncionais. Concebido pelo cartunista Matt Groening com um espírito libertário, Os Simpsons foi um dos principais responsáveis pela construção do império televisivo da Fox, a mais conservadora das redes norte americanas. Protagonizado por Homer Simpson, um anti-intelectual, foi estudado por filósofos, religiosos, psicólogos e cientistas.

Figura 3

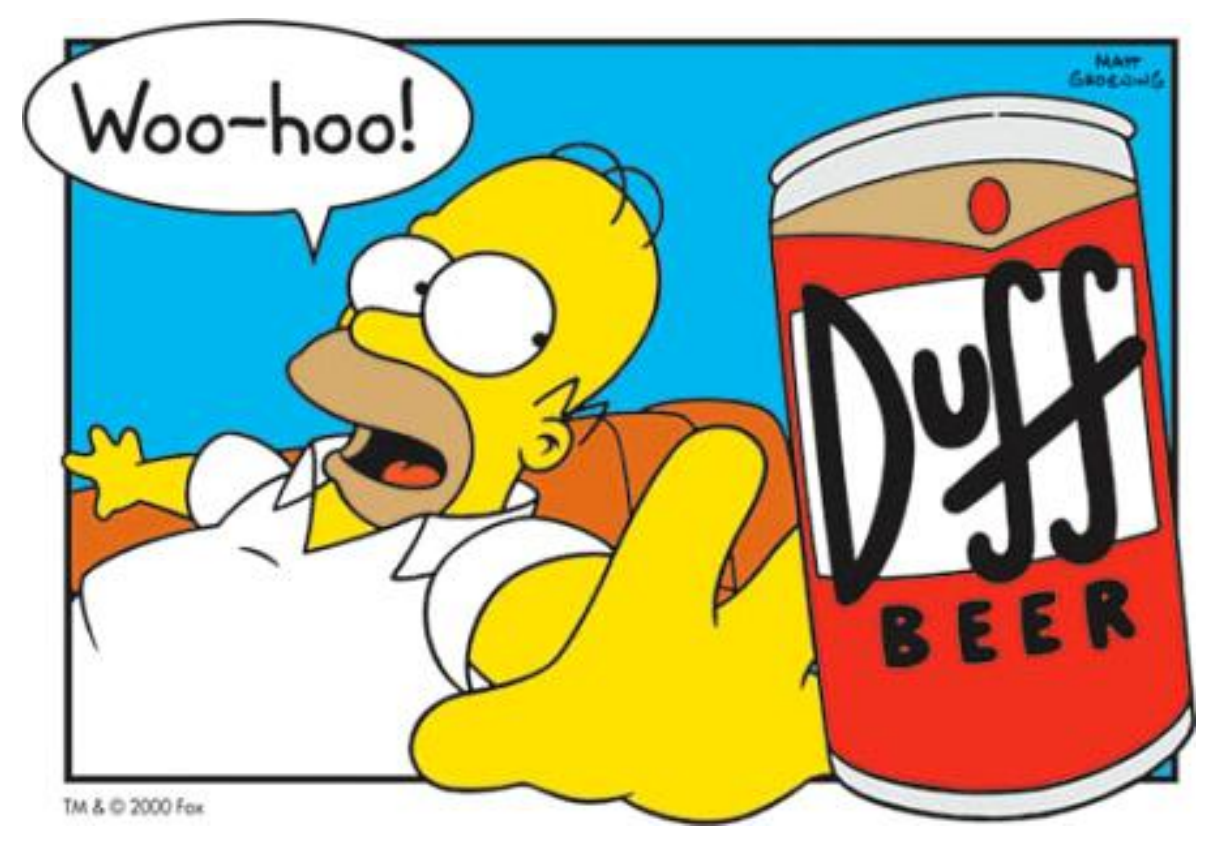

Produzido dentro da lógica comercial da televisão e do merchandising, tornou-se um dos maiores êxitos artísticos dos últimos 20 anos. Isso mesmo: a resposta à pergunta do titulo deste artigo - Os Simpsons é arte? - é um sonoro "sim". O elogio mais comum à série é que ela capta com perfeição o Zeitgeist, o espírito do nosso tempo. E não se pode negar essa constatação: ao criar um desenho estrelado por um sujeito consumista e apolítico, viciado em TV, e satisfeito com a própria ignorância, Groening fez um retrato preciso não apenas do americano médio, mas de um certo padrão global na virada do milênio - não foi à toa que o apresentador William Bonner definiu o espectador comum do Jornal Nacional como um Homer Simpson. (BRAVO,) 
Tudo isso é fato. Mas até aí o talento de Groening poderia ser reduzido à caricatura bem-sucedida. Os Simpsons é uma forma de arte porque vai além e cria um universo com regras particulares baseado em um exagero do mundo real, mas criado com tal complexidade e consistência que termina por influir decisivamente na realidade na qual se inspira.

Autor do livro O Evangelho Segundo os Simpsons, o jornalista e escritor norteamericano Mark pinsky compara, em entrevista a Bravo!, a obra de Groening à do pintor flamengo hieronymus Bosch (1450-1516) - que retratava os pecados e temores religiosos do homem medieval em composições fantásticas e diabólicas. Hoje, quando pensamos na Idade Média, é comum lembrarmos da visão de Bosch (que antecipa em alguns momentos o Surrealismo) como um registro revelador daquele período. No futuro, possivelmente olharão para o desenho animado de Groening como uma tradução confiável do nosso tempo. Em outras palavras, Os Simpsons é um produto do mundo atual, mas o mundo atual é também um produto dos Simpsons.

Um dos mais aguardados produtos culturais das ultimas décadas, Os Simpsons - O Filme é um bom exemplo do método de Groening e sua equipe: eles pegam um tema urgente da atualidade (a questão ambiental) e the dão um tresloucado tratamento ficcional (Homer acidentalmente polui o rio de Springfield com lixo tóxico da usina onde trabalha, perdendo seu emprego, levando à evacuação da cidade e colocando todo o planeta em risco); mas, como a sátira do desenho costuma ser precisa, o resultado conduz a reflexões pertinentes sobre a realidade. Não seria absurdo se uma pesquisa revelasse que as pessoas compreenderam melhor o perigo nuclear com os Simpsons do que com acidente de Chernobyl."

Esse desenho animado parece ser de fato uma obra de arte que retrata a nossa época como alguns pintores da Idade Média retrataram seu tempo nos seus quadros. 
Mas algumas pessoas não conseguem compreender o espírito de nosso tempo captado nas histórias em quadrinhos e nos desenhos animados. Por que não podemos utilizar esse meio de expressão na Universidade e na Educação?

Poderia haver mais pesquisadores e desenhistas de histórias em quadrinhos nas Universidades. Para isso será necessária a criação de uma área de estudo para a Arte Seqüencial da qual haverá o ensino, pesquisa e produção. O próprio Will Eisner ministrava essa disciplina na Universidade de New York.

As histórias em quadrinhos poderiam ser mais popularizadas no meio acadêmico devíamos repensar sobre o papel da arte seqüencial na universalização do saber como propagador de novas idéias surgidas nos ambientes de pesquisa. $\mathrm{O}$ uso das imagens misturadas com texto não é algo novo como diz Wil Eisner nessa citação:

"As histórias em quadrinhos lidam com dois importantes dispositivos de comunicação, palavras e imagens. Decerto trata-se de uma separação arbitrária mas que parece válida, já que no moderno mundo da comunicação esses dispositivos são tratados separadamente. $\mathrm{Na}$ verdade, eles derivam de uma mesma origem, e no emprego habilidoso de palavras e imagens encontram-se o potencial expressivo do veículo. Essa mistura especial de duas formas distintas não é nova. Fizeram-se experimentos com a sua justaposição desde os tempos mais antigos. A inclusão de inscrições, empregadas como enunciados das pessoas retratadas em pinturas medievais, foi abandonada, de modo geral, após o século XVI. Desde então, os esforços dos artistas para expressar enunciados que fossem além da decoração ou da produção de retratos limitaram-se a expressões faciais, posturas e cenário simbólicos. $O$ uso de inscrições reapareceu em panfletos e publicações populares no século 
XVIII. Então, os artistas que lidavam com a arte de contar histórias, destinada ao público de massa, procuraram criar uma Gestalt, uma linguagem coesa que servisse como veículo para expressão de uma complexidade de pensamentos, sons, ações e idéias numa disposição em seqüência, separadas por quadros. Isso ampliou as possibilidades da imagem simples. No processo, desenvolveu-se a moderna forma artística que chamamos de histórias em quadrinhos (comics), e que os franceses chamam bande dessinée." (EISNER, 1977.)

$\mathrm{Na}$ Internet encontramos vários Sites interessantes que ensinam como criar histórias em quadrinhos. São muito impressionantes as técnicas que os quadrinhistas utilizam para desenvolverem tanto o roteiro quanto as seqüências de cada quadro.

As histórias em quadrinhos são muito dinâmicas e mudaram muito desde o seu surgimento. Elas incorporaram vários elementos de outras áreas afins como, por exemplo: o cinema, a literatura, e a ficção cientifica etc.

A universidade precisa ter um olhar renovado sobre o tema das histórias em quadrinhos. Hoje em dia esse tema está sendo cada vez mais comum por isso há possibilidade de se dar mais um passo à frente no futuro, pois as universidades serão cada vez mais interessadas desenvolver técnicas para fazer histórias em quadrinhos. Por isso seria preciso até uma criação de uma universidade de quadrinhos aqui no DF formando profissionais de arte seqüencial que às vezes faltam. Quando a universidade ou editoras precisam desses profissionais não existe uma organização sólida em torno das produções de histórias em quadrinhos para vencer as dificuldades desse mercado de trabalho. O comentário mais comum das áreas afins sobre a profissionalização do quadrinhista é que "histórias em quadrinhos não dão dinheiro". Há um fundo de verdade nessa afirmação 
porque vivemos numa sociedade onde o dinheiro comanda diversas áreas e tudo gira em torno de sua aquisição. A cultura é sempre posta em segundo plano, ou até em ultimo plano, mas ainda existe uma esperança de se criar o curso de arte seqüencial no Departamento de Artes Visuais na Universidade de Brasília-UNB.

\section{Proposta de Criação de uma Oficina em Arte Seqüencial na Universidade}

Muitas pessoas não acreditam em uma Universidade de Arte Seqüencial porque essas mesmas pessoas não se interessariam na sua criação porque a profissão de artista de quadrinhos não dá status nem reconhecimento por parte da população. Até a idéia de uma oficina de quadrinhos foi criada com intuito de se promover uma experiência para tentarmos colocar a teoria em prática porque às vezes falamos demais e agimos pouco, por isso decidimos ver se esse projeto é mesmo viável, mesmo que não esteja oficializado na universidade por enquanto esse é o primeiro passo para a realização desse sonho, e este projeto é apenas um primeiro passo.

Sabemos das dificuldades no início e também da nossa falta de experiência do assunto é mesmo um desafio, poucas pessoas acreditam na capacidade das pessoas de vencer os problemas que são impostos pela vida sei que é complicado o projeto sair do papel, mas tenho esperança que tudo vai dar certo.

A idéia da criação da oficina dos quadrinhos foi criada nessa data 05/10/2007 onde eu e alguns calouros de artes plásticas mais alguns alunos de outros cursos, decidem fazer fanzines nas salas vazias que não tinham aula até arrumar um local específico. Alguns alunos acharam a idéia genial, mas no primeiro dia da aula ninguém apareceu, mas acho que isso aconteceu por causa do feriado prolongado. O projeto da Universidade dos quadrinhos foi elaborado na disciplina PI "Projeto interdisciplinar". O nome do projeto desenvolvido chama-se "Universidade dos quadrinhos" cujo objetivo é ser um projeto de inclusão social 
e um espaço de cultura para comunidade. A Universidade dos quadrinhos -UQ transformará o Distrito Federal num grande pólo de desenvolvimento de artes por que nessa Universidade existirão cursos em Arte Seqüencial, Animação, produção de Cinema, Ilustração de livros, Arte eletrônica, cursos de Desenho, Editora de livros entre outros.

Haverá também uma Biblioteca com livros atualizados sobre arte, terá uma gibiteca e uma videoteca onde serão arquivados todos os trabalhos que serão produzidos pela UQ. Objetivo dessa Universidade é a valorização dos artistas do Distrito Federal por que será um local de eventos que terá um grande auditório onde outros artistas que não são de Brasília serão convidados como palestrantes.

O Distrito Federal e o entorno tem grandes talentos na área de arte seqüencial que, porém, não têm apoio financeiro e não têm como publicar suas histórias porque as editoras não vêem retorno financeiro e por isso os desenhistas de quadrinhos amadores não têm a chance de expor seu trabalho para um público maior e que tenha o interesse de conhecer novos trabalhos.

Vendo a dificuldade desses artistas a UQ vai proporcionar que as histórias em quadrinhos deles sejam publicadas gratuitamente, mas em contrapartida eles vão deixar alguns exemplares na gibiteca da UQ onde poderão ser lidas pelos leitores e pesquisadores.

A gibiteca da UQ será um espaço aberto ao público que poderá ler as histórias em quadrinhos produzidas por artistas do DF e entorno, e se estes artistas quiserem também podem se associar a UQ para exporem seus trabalhos. A Universidade dos Quadrinhos vai oferecer cursos pra quem tiver interesse em aprender técnicas de fazer historias em quadrinhos. No currículo haverão disciplinas para formar desenhistas, roteiristas, arte finalistas etc. 
Seremos grandes pesquisadores desse assunto, pois iremos treinar todos os dias para aperfeiçoar nossa arte e não desistiremos facilmente ante as tribulações diárias. Todo material que encontrar como, por exemplo: livros, artigos, Sites, revistas, etc, sobre o tema histórias em quadrinhos será arquivado para eventual consulta. Já comecei a fazer essa pequena Biblioteca porque são necessários materiais de pesquisa.

A partir de agora levarei mais a sério as pesquisa para desenvolver 0 projeto da Universidade dos Quadrinhos. Em minha avaliação, talvez não tive um resultado satisfatório até agora por falta de empenho e dedicação sei que não deveria escrever isso na monografia, mas vou ser sincero comigo mesmo, e descobri que quando não trabalhamos seriamente em uma pesquisa ela acaba não ficando boa.

Preciso explorar melhor minhas idéias e escrever com mais vontade não vou ter mais medo de errar, daqui para frente tenho que perder as minhas fobias e complexos, caminharei e aprenderei com essas falhas e com erros e acertos, pois é assim que se adquire mais experiência. Sempre tive medo de executar qualquer empreendimento para me situar numa zona de conforto imaginária, mas a partir de agora me convenço que tal lugar de paz não existe. A vida é uma questão de luta e sobrevivência dos mais aptos, por isso decidi aperfeiçoar melhor o meu projeto e conseqüentemente essa monografia.

Qualquer idéia que tiver vai ser posta no papel impiedosamente, como disse antes às vezes tenho medo de errar esse é o meu maior dilema, quando temos tudo para fazer uma monografia cada vez melhor acabamos por nos acomodar. O sucesso da oficina de quadrinhos é um bom sinal se tudo der certo, vai ser uma grande vitória para execução desse projeto, se ninguém me ajudar não ficarei desolado e sim procurarei melhorar o projeto. 
Se depender de mim vai dar tudo certo, por isso vou anotar tudo que acontecer daqui para frente, se possível vou filmar e gravar as aulas da oficina dos quadrinhos para que fiquem mais proveitosas e cada vez mais histórias em quadrinhos venham ser produzidas pelos alunos.

Superarei tudo que acontecer não podemos retroceder num momento tão decisivo no Departamento de Artes-IDA, por isso prepararei as aulas cuidadosamente anotarei todos os planos de aula como aprendi na disciplina de Estágio Supervisionado.

A partir de agora sinto que tudo vai dar certo estou com idéias mais consistentes do que no inicio quando comecei a escrever essa monografia. Fiquei algum tempo sem escrever nada perdi um tempo valioso e por isso não posso cometer esse mesmo erro, a minha orientadora, professora Cristina Barrenechea, até disse que eu sou um aluno surpreendente por que algumas pessoas pensam que eu não faço nada e não acreditam na minha capacidade de realização de trabalhos. Felizmente sei dessa minha característica de vencer desafios e deixar as outras pessoas boquiabertas com minha capacidade e força de vontade de sair vencendo no final, digo isso com fatos, fui o primeiro aluno a fazer a monografia da minha turma e não é só isso o nosso curso de artes plásticas noturno tirou o melhor rendimento de toda UNB.

Temos muitos talentos que se não formos desenvolvê-los acabamos não tendo a vitória nos momentos decisivos, eu completei trinta anos no dia 24/10/2007 eu tenho três décadas de lutas e desafios e posso dizer para todos que quiserem saber que sempre fui um dos melhores alunos sempre me destaquei nos estudos consegui vencer quando muitos não acreditavam em $\operatorname{mim}$.

O meu projeto "Universidade dos Quadrinhos" vai dar certo por que vai ser só mais um desafio que vai ser superado com esforço e dedicação, já assisti uma oficina de $H Q$ na Universidade católica de Brasília-UCB, não 
lembro o nome da professora agora, mas eu guardei uma frase que ela disse que é assim. "Os brasileiros podem ser os melhores no que fazem não apenas no futebol somos os melhores, os brasileiros vão fazer das histórias em quadrinhos o que fizeram com o futebol".

Isso me incentivou a escrever essa monografia sobre histórias em quadrinhos não escolhi esse tema apenas por achá-lo interessante e sim por que acredito no potencial do Brasil e dos brasileiros de tornar um esporte em um espetáculo e com certeza vamos tornar as HQs brasileiras verdadeiras obras de artes, afinal não é a toa que dizem que Deus é brasileiro.

A cultura brasileira é muito rica e diversificada e muito mal divulgada no exterior por que só mostramos o lado negativo do Brasil, sabemos que existem muitos problemas nesse grande país, mas qual é o país que não tem problemas? As HQs deveriam mostrar a cultura brasileira, que deveria mostrada de maneira espontânea, como acontece nos mangás japoneses. Porque só falar da pobreza e da violência, será que no Brasil só existe pobreza e violência?

Poderíamos falar de fatos importantes para o país como o inicio da colonização a descoberta do Brasil, os grandes fatos que marcaram a história do Brasil. Poderíamos falar da cultura dos índios, dos africanos, dos imigrantes, existem inúmeros temas pouco explorado. Por exemplo, há uma tendência de fazer charges sobre políticos no Brasil que já é quase uma tradição, mas por que não podemos escrever sobre coisas mais positivas sobre o que deu certo nesse país.

A cultura de se fazer histórias em quadrinhos não pode ficar tão resumida a um só tema crítico, precisamos retratar o potencial de um povo, de um país continental, a nossa força cultural não pode ser desperdiçada senão ficaremos batendo em uma tecla só. 
Eu sei que vai ser difícil escrever histórias em quadrinhos com temas que o Brasil é um país vencedor por que algumas pessoas desprezam a nossa capacidade de sermos um grande país no mundo preferíamos acreditar que somos mais inferiores em nossa capacidade de executar grandes realizações culturais.

O dinamismo do povo brasileiro é espetacular por que apesar de vivermos duras crises financeiras e não temos um bom sistema de educação, hospitalar, transporte público, etc, ainda assim temos a esperança de dias melhores e somos muito otimistas mesmo quando tudo dá errado para nós, como dizem os ditados populares: "levanta e sacode a poeira"; "Bola para frente" entre tantos, essa é uma característica do povo brasileiro que devia ser explorada nas histórias em quadrinhos, não só os insucessos e nossos problemas com os políticos. Parece que algumas pessoas estão se acomodando e acreditando que o Brasil é assim mesmo e que a má qualidade da nossa política é algo normal, e que nunca conseguiremos mudar o nosso destino.

Vamos mudar essa mentalidade nem que isso comece nas histórias em quadrinhos, vamos conscientizar a nossa juventude de que somos um país vencedor e que não precisamos emigrar do Brasil para o exterior para termos sucesso lá fora como muitos talentos artísticos brasileiros fazem, a começar pelos desenhistas de quadrinhos que chegaram a mudar seus nomes de origem brasileira para serem aceitos por países estrangeiros que discriminam imigrantes brasileiros só explorando o seu trabalho artístico e depois os revendendo para o Brasil como se fossemos um país que não sabe valorizar os seus próprios filhos, os filhos dessa nação. Porque o Brasil só valoriza seus artistas depois que fazem sucesso no exterior? 
Deveríamos acabar com esse tipo de postura que só prejudica nossa imagem, acho que até esse comportamento poderia ser estudado em nossa cultura; o da depreciação de seus cidadãos que são sempre colocados como artistas de segunda categoria reputando como "bons" apenas os que estudaram no exterior e que de alguma forma conseguiram ter sucesso fora de seu país de origem.

No Distrito Federal não temos uma universidade dos quadrinhos pública, algumas pessoas poderiam dizer que não há essa necessidade porque há outras prioridades mais urgentes como reformar as escolas, investir em saúde ou em segurança etc, mas esse tipo de raciocínio é muito simplista e trata a questão com muito pouco caso. É claro que devemos investir em necessidades básicas da sociedade sem dúvida, mas isso não passa de mais um pretexto para deixarmos as coisas como estão, ou seja, ficamos com as duas coisas, ou sem as duas coisas, não temos saúde, nem educação, nem segurança e muito menos vamos ter uma universidade só para quadrinhos. Vamos deixar do jeito como está, segundo essas pessoas pragmáticas e que não querem investir na produção cultural. Não podemos ficar misturando as coisas, cada segmento da sociedade precisa ser valorizado, não podemos pensar com demagogia.

A construção de Brasília representou para o Brasil um símbolo de que os brasileiros são capazes de construções e criações, onde antes era um deserto e onde era longe de tudo, com apenas esse espírito do povo brasileiro podemos construir uma estrutura para criação de novas histórias em quadrinhos representando uma nova história pra o Brasil nesse milênio.

Vamos sonhar mais e esquecer um pouco o que nos aflige e concentrar mais naquilo que somos melhores como, por exemplo, nossa famosa "criatividade" que agora se transformou em um diferencial positivo para as 
nações, pois somente os mais criativos e inventivos conseguiram resultados espetaculares nesse novo mundo da tecnologia e da globalização.

Seremos bons criadores de histórias em quadrinhos porque sempre fomos bons em sermos criativos e para fazer um bom roteiro de $H Q$ é necessário ter essas qualidades. Isso o povo brasileiro tem de sobra principalmente as pessoas mais humildes que não tem condições de pagar uma escola particular.

Quero que todos saibam que se dermos apenas educação de boa qualidade somente para quem tem condições financeiras para ter acesso a essas escolas, o Brasil sempre será uma nação desigual e seremos sempre um país subdesenvolvido para sempre. Por isso quero utilizar a Universidade dos Quadrinhos para melhorar o nível de Educação do Distrito Federal e regiões do entorno e se tudo der certo, se houver mesmo uma melhoria na qualidade da educação por meio da inclusão social, o projeto vai se expandir para outras regiões brasileiras. Mas primeiro vamos tornar o DF em uma ilha de excelência onde tudo vai ser de alta qualidade como a educação, transporte e saneamento básico.

A universidade dos quadrinhos e sua equipe de profissionais qualificados vão fazer histórias sobre quais são os problemas do DF hoje, mas para isso contará com o respaldo técnico de especialistas de cada área para as histórias contarem os fatos com veracidade, com isso os leitores dessas histórias em quadrinhos que antes eram leigos de vários assuntos vão se tornar cada vez conscientes com sua cidadania.

Afirmo isso em virtude da facilidade de que os quadrinhos facilitam a aprendizagem como esse trecho em inglês do livro "Dream Japan":

"For translator, or an interpreter, or any nonnative speaker who aspires to true fluency in spoken japanese, 
reading mangá is one of the best ways to keep up with the many changes that are constantly occurring in the Japanese language. The language in mangá is alive and closer to the "street" than one finds in other printed media, and it is a source of many new expressions. Because of their visual nature, mangá can also be an excellent language learning resource for beginning students of Japanese. In what is surely one of the most interesting experiments in American publishing in recent years, in 1990 Vaughan Simmons, an American in Atlanta, Georgia, took this idea to its logical conclusion and began publishing Mangajin, a magazine that uses mangá with English explanations to teach Japanese language and culture; when readers tire of struggling with unfamiliar kanji characters, they can relax and enjoy the English explanations or the pictures."

Poderíamos pensar na seguinte perspectiva: se os mangas japoneses fizeram um tremendo sucesso na cultura pop e que muitos leitores passaram a se interessar por aspectos da cultura oriental em virtude dessa forma de leitura, talvez o Brasil pudesse utilizar não só o estilo mangá, mas variados estilos de quadrinhistas para retratar bem sua cultura. Podemos ver o Brasil como potência na criação de HQs juntamente com o Japão e os Estados Unidos e Europa.

Muitos desenhistas de histórias em quadrinhos têm dificuldades de encontrar espaço no mercado por causa da concorrência de gibis estrangeiros, o que de certa forma é um massacre porque as editoras brasileiras só publicam o que dá lucro e não acreditam no potencial do quadrinhista nacional.

Ao irmos à uma banca de revistas hoje só encontraremos títulos estrangeiros pois uma das poucas revistas em quadrinhos nacional que conseguiu se manter no mercado foi a turma da Mônica de Maurício de Souza, temos também o Ziraldo em uma menor escala. 
Não vejo esse fato com muito orgulho, muito embora eu parabenizo o Mauricio de Souza por ter conseguido se manter nesse mercado e ser um exemplo de sucesso, mas notamos que a situação do quadrinho nacional é muito excluída e não é levada a sério dentro da universidade, enquanto um campo de formação.

Não podemos nos conformar com essa situação, porque os gibis brasileiros estão em total abandono por parte do governo e muitas pessoas desprezam esse ótimo meio de comunicação e que está sendo muito mal utilizado? Escrevo esta monografia por que acredito que haverá sinais de melhora para esse segmento, estou apenas começando a pesquisar o assunto mas é bom pensamos positivamente para o futuro.

As histórias em quadrinhos vão contribuir muito para a o novo sistema educacional que irá surgir e com introdução da educação a distância pela Internet haverá uma demanda muito grande por esses profissionais da área do desenho.

Então teremos que preparar essas pessoas para se tornarem esses profissionais no futuro, para isso começaremos com pequenas oficinas de quadrinhos para ganharmos experiência na produção de histórias em quadrinhos com isso também lendo vários livros que falam sobre o assunto.

Vamos aos poucos criando pequenas histórias em quadrinhos, mas constantemente mesmo que não fiquem bem feitas no início, por que o objetivo agora não é sermos os melhores e sim termos uma boa base e uma vasta experiência.

Por enquanto procuro ler alguns sites que falam sobre esse assunto e estou adquirindo alguns livros e apostilas e também escrevendo e desenhando algumas histórias simples que nada lembram um trabalho profissional, mas 
como diz o ditado "É melhor pingar do que secar". Será melhor nós criamos nossas historinhas simples e amadoras do que ficarmos parados sem ação só criticando e não fazendo nada para mudar essa situação.

Se cada um ajudar de alguma forma poderíamos contribuir para o fortalecimento do Gibi nacional, pois historicamente tivemos alguns quadrinhos de valor:

\begin{abstract}
"Assim como a história em quadrinhos norte americana tem como marco o aparecimento do garoto amarelo num suplemento dominical, em 1895, no Brasil, segundo Moacy Cirne (1990, p.16), o primeiro quadrinho foi publicado em 1869, na revista Vida Fluminense. As aventuras de Nhô Quim contavam, em episódios, as desventuras de um homem simples do interior do país. Embora houvesse publicações de histórias como as Nho Quim, charges políticas e caricaturas, o ano de 1905 é sem dúvida mais emblemático, pois foi no dia 11 de outubro que a editora $O$ Malho lançou a revista TicoTico, primeira publicação idealizada especificamente para crianças. O Tico-Tico era uma revista em cores e foi baseada na revista francesa La semaine de Suzette, que no Brasil era publicada com o nome de Felismina. A revista trazia duas seções intituladas "Lições de vovô" e "Correspondência do Dr. Sabe tudo" e as histórias de Chiquinho. Considerado um personagem tipicamente brasileiro, Chiquinho era, na verdade, uma versão Buster Brown. A história foi adaptada para a realidade brasileira por meio de argumentos de autores nacionais que, a certa altura, introduziram um personagem que nunca existiu no original americano: o preto Benjamim. Sem contar as participações de Mutt e Jeff como personagens coadjuvantes em algumas histórias de Chiquinho ou Zé macaco, criado por Alfredo Stomi em 1908. Todas essas adaptações eram assinadas por autores brasileiros, o que, de acordo com Álvaro de Moya (1993, p. 35), levou Chiquinho a ser erroneamente considerado o típico quadrinho nacional durante muitos anos. O Tico-Tico também publicava, sem nenhuma adaptação, histórias como $O$ Ratinho Curioso (Mickey Mouse), o Gato Felix, Chiquita (Becassine) e outras hqs.Embora Chiquinho fosse um sucesso adaptado, a revista lançou muitos personagens genuinamente brasileiros: Tinoco, - caçador de feras; Bolinha; Chico Muque e o Barão de Rapapé e os famosos Reco-Reco, bolão e Azeitona. Em 1934, foi lançado o Suplemento Juvenil, do jornal A Nação, que é considerado pelos teóricos o desencadeador dos comics no Brasil. Para concorrer com o Suplemento, Roberto Marinho, de O Globo Juvenil, em 1937, e a revista Gibi de 1939, que se
\end{abstract}


tornou sinônimo de histórias em quadrinhos. Outras revistas foram publicadas.

\section{Oficinas de quadrinhos}

A revitalização da produção de HQs à princípio parecia uma tarefa fácil, mas não é. Seria necessário um esforço fenomenal para que isso acontecesse, a começar pela falta de incentivo do governo e dos próprios quadrinhistas muitos deles não sabem trabalhar em equipe e só pensam em publicar algumas histórias para ficarem conhecidos em seus círculos de amizades. Mas trabalhando dessa forma não almejam produzir histórias em quadrinhos periodicamente e atrasam muito o processo de produção de uma HQ. É preciso se descobrir um jeito de superar essa lentidão por parte de alguns quadrinhistas que, agindo sem entusiasmo na produção das HQs acabam por não colaborar para o impulso da indústria de quadrinhos no DF.

Há também uma certa concorrência entre os autores de fanzine que acaba por ser prejudicial para o plano de ressurgimento da cultura de criação de gibis, mas o público mesmo que reduzido têm interesse de conhecer a produção local de histórias do Distrito Federal. O projeto em si poderá contar com o apoio da universidade e algumas agências de pesquisa, o espaço poderá ser cedido pelo governo ou os interessados nesse projeto.

Por mais que se lute na execução do projeto de ensinar como fazer histórias em quadrinhos mais problemas vão surgindo e que precisam ser solucionados. À principio deverão ser feitas algumas alterações e se ter um empenho maior na produção, mas o que importa agora é a aceleração da produção dos $\mathrm{HQ}$ e os idealizadores do projeto colocarem a mão na massa para que sirva de exemplo para os futuros colaboradores desse pŕojeto de produção de $H Q$. 


\section{Conclusão}

O DF necessita desse espaço de cultura para dar oportunidade para os jovens que se interessem pela arte seqüencial. É preciso implantar o mais rápido possivel uma alternativa de ensino para as novas gerações que vão surgindo, existe uma crítica muito grande sobre os quadrinhos dizendo que eles alienan os jovens, mas a produção de histórias deles próprios pode servir como um espelho para eles mesmos.

A indústria de quadrinhos se apoiará firmemente nesses novos talentos que irão surgir a partir dessas oficinas e para isso é necessário uma séria dedicação enquanto alguns alunos de artes, comunicação ou desenho industrial que são bons desenhistas em histórias em quadrinhos, mas que não ensinam em oficinas em quadrinhos a técnica da arte seqüencial. Muitos jovens vão se perdendo nas drogas e se envolvem com o crime, temos que oferecer as oficinas de quadrinhos urgentemente para resgatar os jovens desse mundo da marginalidade, mas para que isso aconteça é necessário uma união verdadeira entre os quadrinhistas que são muito desunidos e essa desunião favorece que os jovens se joguem para caminhos errados. $O$ jovem não quer só ser consumidor de histórias em quadrinhos, mas também quer produzir as suas próprias histórias.

É muito triste ver como é esse mundo aqui no DF, as pessoas acham que ser bem sucedido é passar em uma universidade pública e passar em um concurso público, porque vivemos em um mundo materialista e individualista. Muitos universitários não querem oferecer nada em troca para a sociedade que financiou seus estudos nessas universidades públicas. Há uma ingratidão muito forte entre os universitários. Será que vamos resgatar a nossa juventude que hoje está sem perspectivas? É necessário que nós os universitários, nos empenhemos por um mundo melhor e uma sociedade mais justa. 
A idéia de se criar uma oficina de quadrinhos pode parecer como algo surrealista e utópico mais na verdade, o que esse sistema capitalista oferece, apenas uma cultura de massa alienante, apesar dos quadrinhos surgirem da cultura de massa ele pode ser o antídoto para esse sistema opressor, se esse projeto se realizar mesmo no futuro, os jovens serão beneficiados e se sentirão orgulhos por produzirem suas próprias histórias em quadrinhos.

As cidades da periferia de Brasília vão ser tornar um celeiro fecundo de novos autores de histórias em quadrinhos, a universidade tem que ir avançar nessas cidades esquecidas pelo poder público, seremos grandes quadrinhistas, o DF vai se vangloriar de sua produção de $\mathrm{HQ}$, apesar de hoje temos uma produção quase inexistente, há um interesse muito grande dos jovens universitários em aprender essas técnicas da arte seqüencial.

O Distrito Federal poderá ser conhecido no cenário internacional como nova opção de histórias em quadrinhos e que terá cativado vários admiradores dessa arte seqüencial desenvolvida em Brasília totalmente oposta aos quadrinhos capitalistas que existem por ai nas bancas, que já estão quase que esquecidos pelos leitores, que estão procurando novas histórias. O DF é o cenário ideal pra essas novas produções.

A Arte Seqüencial pode ser usada em todos os níveis da educação, inclusive na educação superior. Uma possível aplicação pode ser a de desenvolver histórias em quadrinhos para apresentar em uma linguagem mais acessível conhecimentos que estão em artigos científicos e teses defendidas para torná-las mais compreensíveis para o público leigo. Gostaria de criar histórias em quadrinhos com temas acadêmicos da Universidade, com intuito de despertar a curiosidade das outras pessoas fora da universidade, para que elas tivessem mais facilidade de entender como funciona uma Universidade. Gostaria de fazer histórias com temas acadêmicos para as crianças se identificassem com a universidade hoje e com os conhecimentos que nela circulam, e não apenas com 
a mera ficção cientifica que é o assunto mais presente nas histórias em quadrinhos.

A universidade é vista como inacessível para os jovens da sociedade só que ela não propõe inovação em sua forma de disseminar os seus conhecimentos. Com os novos meios de comunicação, sabemos que jornais e revistas são usados para expor trabalhos acadêmicos, mas por que não podemos utilizar histórias em quadrinhos para essa mesma tarefa?

Não sei se alguém já teve essa idéia, mas eu sugiro que se desse maior atenção para se transformar as teses acadêmicas em histórias em quadrinhos, pois com o uso dos desenhos associados ao texto com certeza podem melhorar e muito a compreensão de inúmeras teses.

A universidade pode ser beneficiada com o talento de novos quadrinhistas que podem surgir entre seus alunos, só falta um incentivo para isso acontecer. Por exemplo, o departamento de Artes Visuais poderia ter uma gibiteca com histórias em quadrinhos de escritores consagrados para eventual consulta.

A elaboração desse projeto pode ser um trabalho pioneiro para incentivar a elaboração de histórias quadrinhos. Tudo é possível para realização desse sonho, de tornar a Universidade de Brasília um pólo de produção de histórias em quadrinhos.

Gostaria de contar com todos os admiradores da arte de criar histórias em quadrinhos para que um dia consigamos a nossa própria Universidade dos Quadrinhos. A disciplina de arte seqüencial é apenas um pequeno passo se ficarmos satisfeitos em apenas ter uma disciplina não estaremos almejando devidamente pela nossa causa que é a construção de um grande Centro Universitário de produção de Histórias em quadrinhos, esta foi a minha motivação inicial para fazer este no projeto. 


\section{Bibliografia}

EISNER, Will, Quadrinhos e Arte Seqüencial, 2ª Edição, São Paulo: Martins Fontes, 1995.

CIRNE, Moacy, Bum! A Explosão Criativa dos Quadrinhos, $5^{\text {a }}$ edição, Petrópolis: Editora Vozes, 1977.

OLIVEIRA, Selma Regina Nunes, Mulher ao Quadrado: as representações femininas nos quadrinhos norte-americanos: permanências e ressonâncias (1895-1990), Brasília: Editora Universidade de Brasília, 2007.

\section{Fontes da Internet}

http://www.eca.usp.br/agaque/agaque/ano2/numero2/artigosn2 1v2.htm Dia: 31/10/2007 Horário: 16:23

http://www.comciencia.br/reportagens/2004/10/13.shtml

Dia: 31/10/07 Horário: 16:36

http://pt.wikipedia.org/wiki/Banda Desenhada

Dia: 31/10/07 Horário: 16:38

http://www.fanboy.com.br/modules.php?name=News\&file=article \&sid=156

Dia: 31/10/07 Horário: 16:54 
Apêndice

llustrações

Figura 4

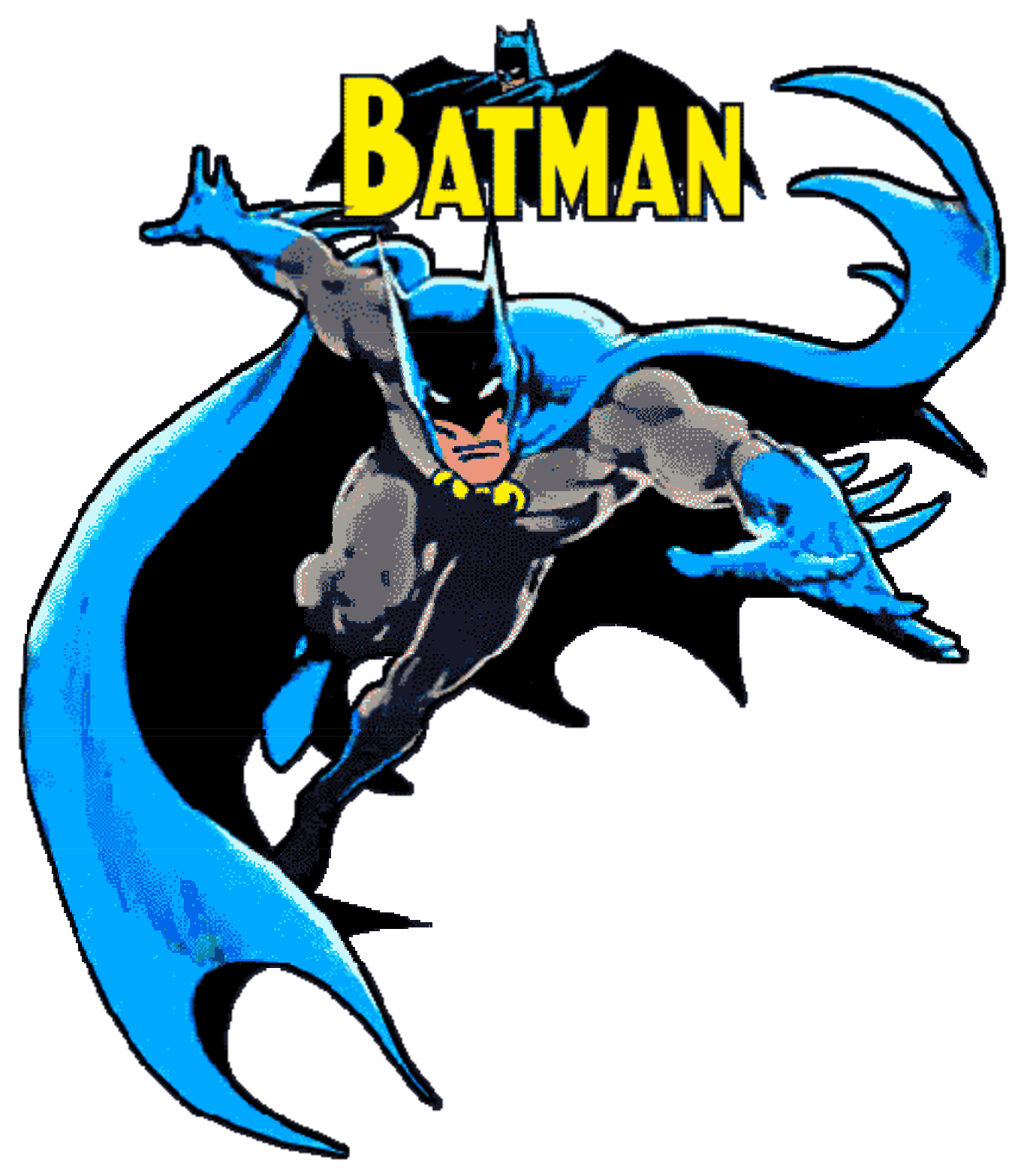


Figura 5

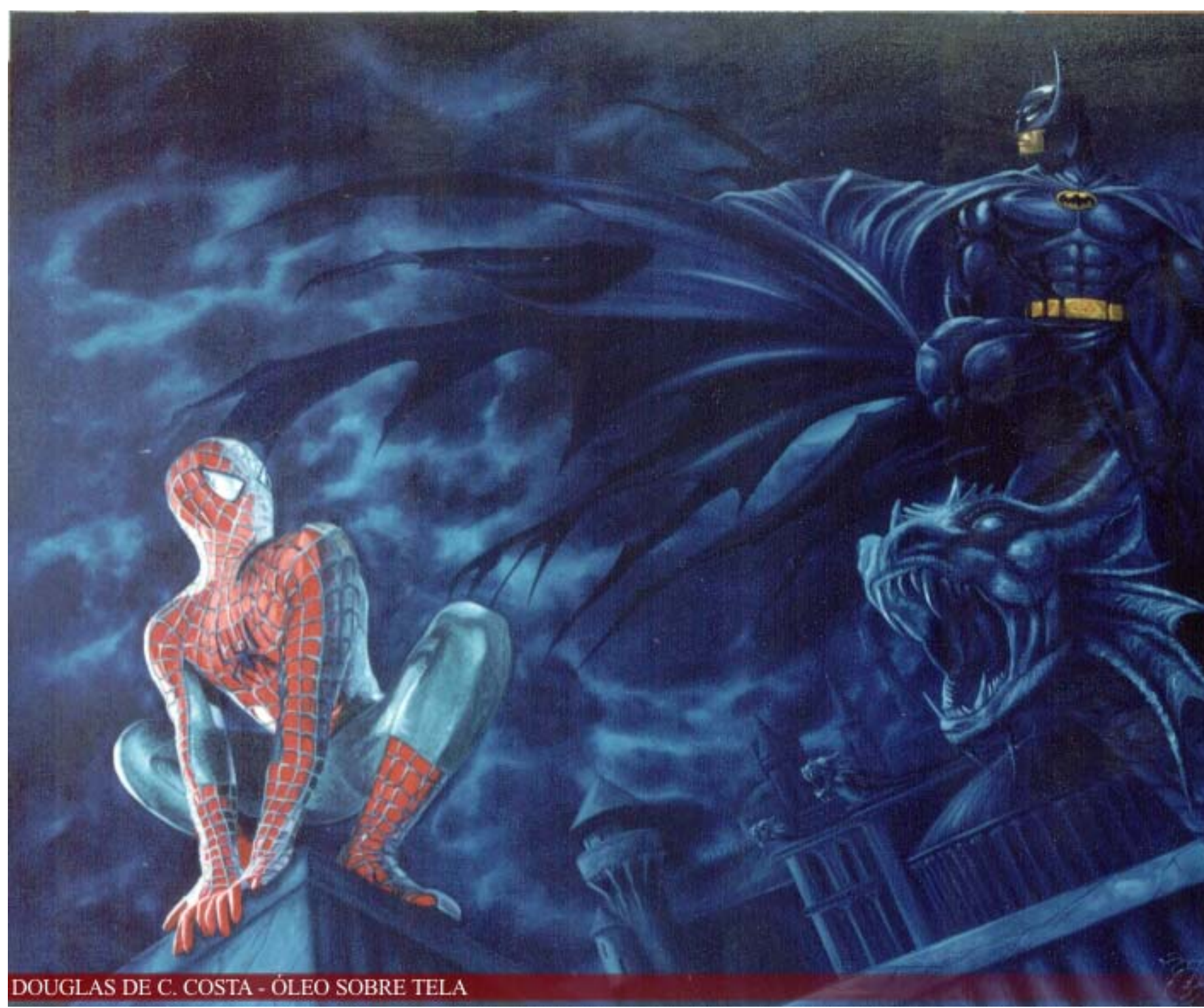

Figura 6 


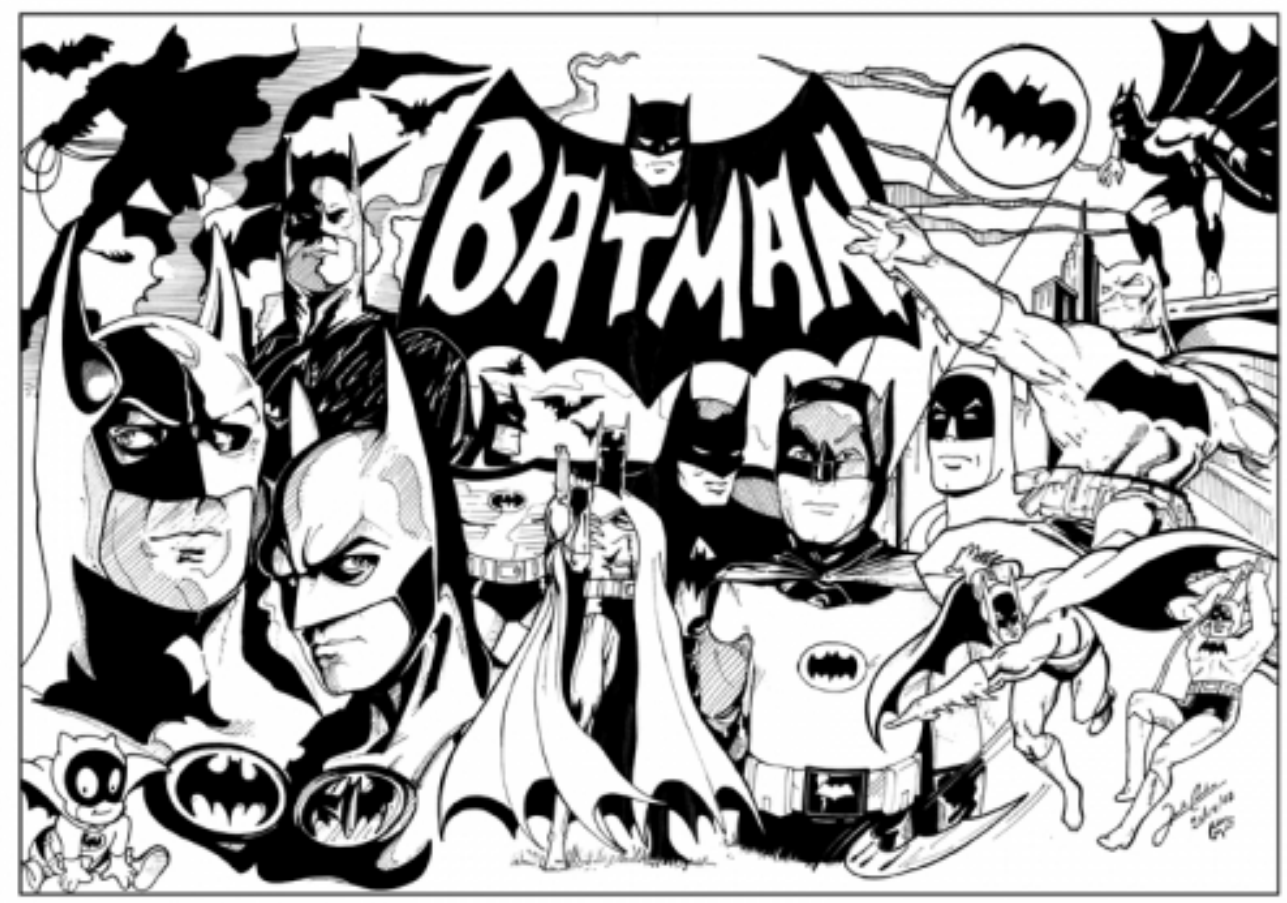

Figura 7 


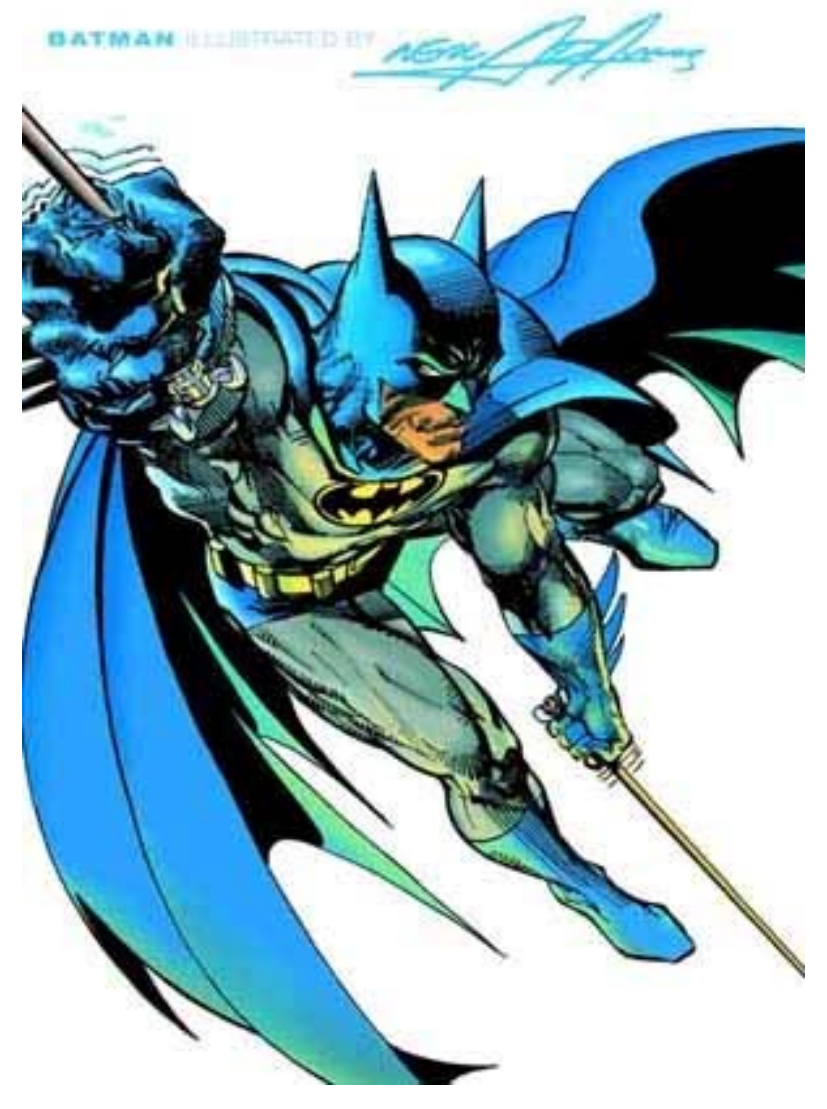


Figura 8

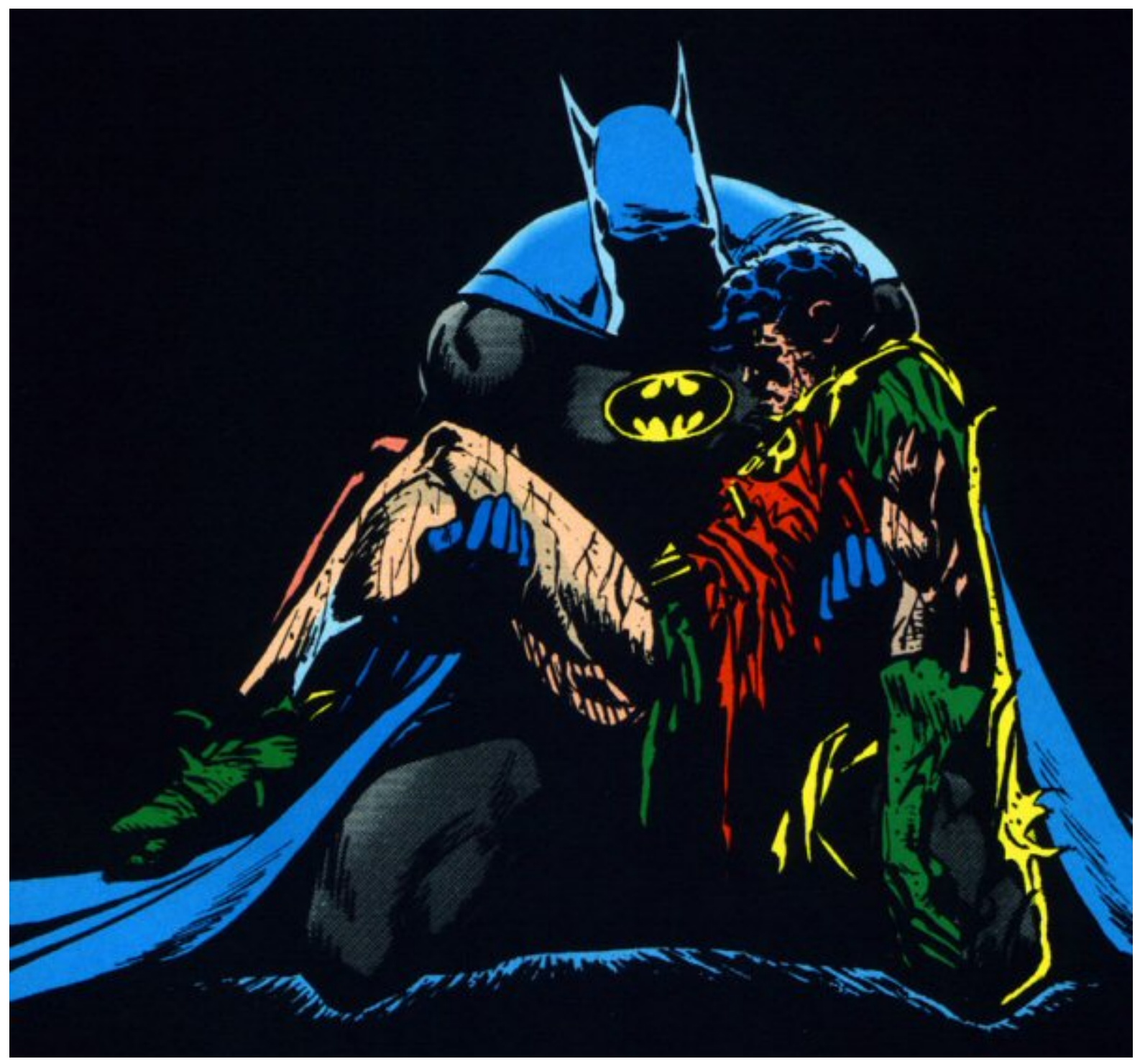


Figura 9

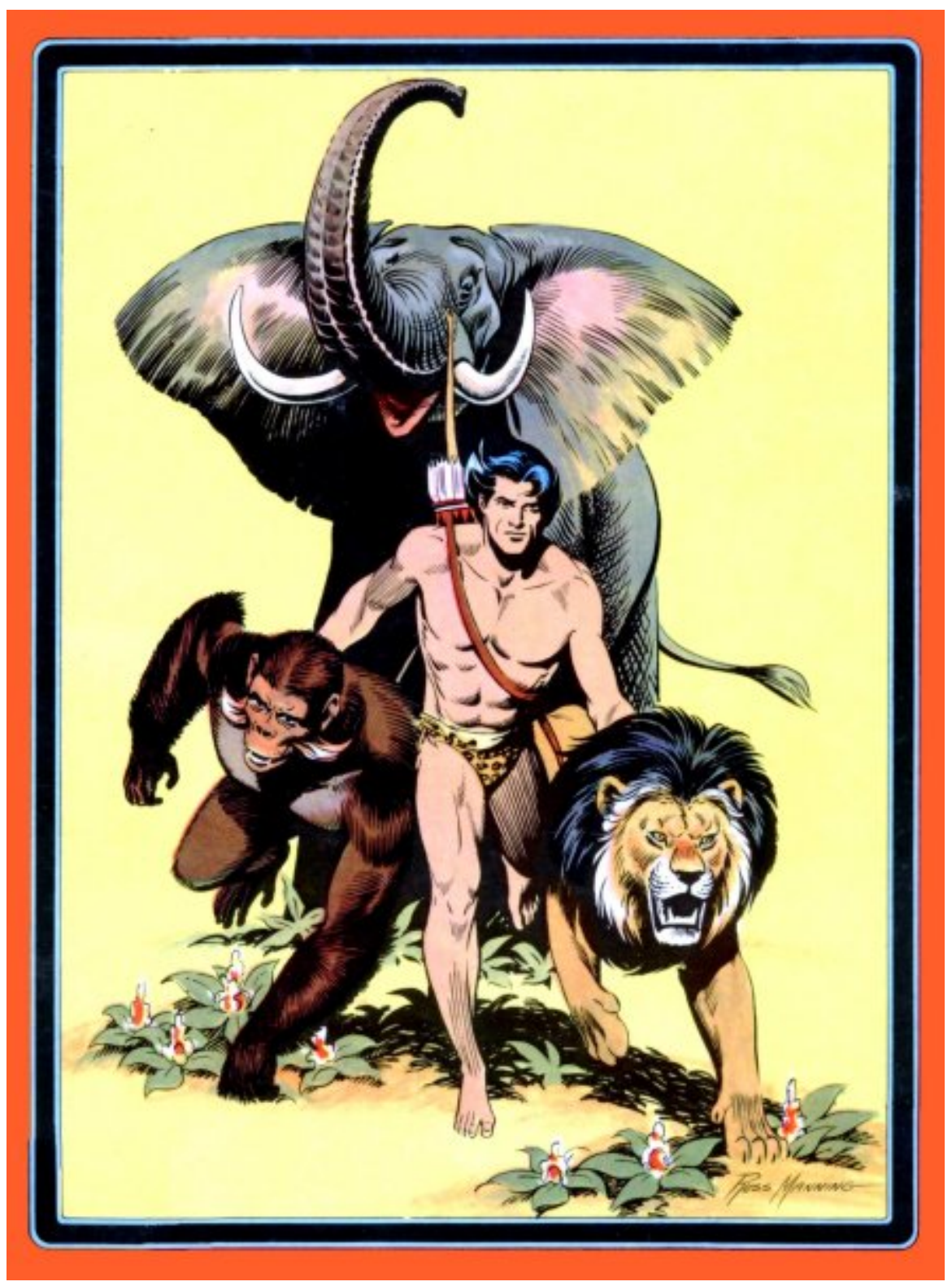


Figura 10

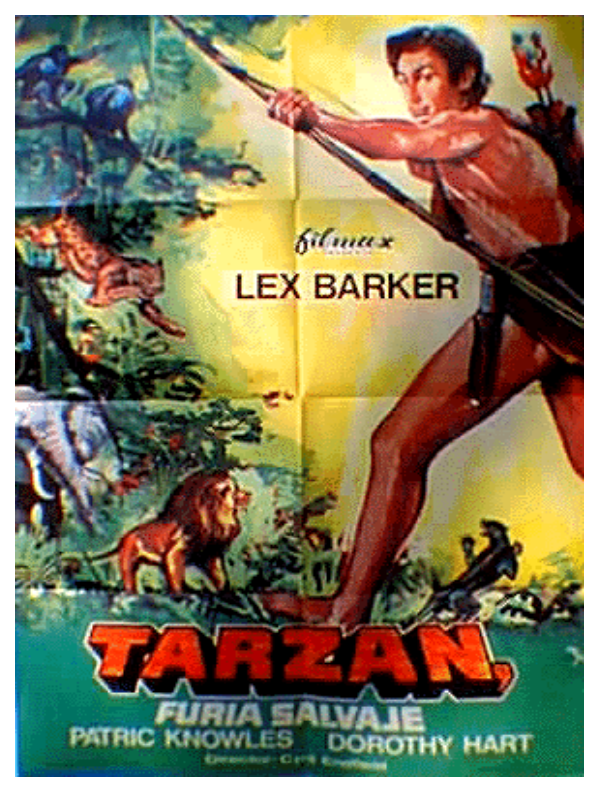


Figura 11

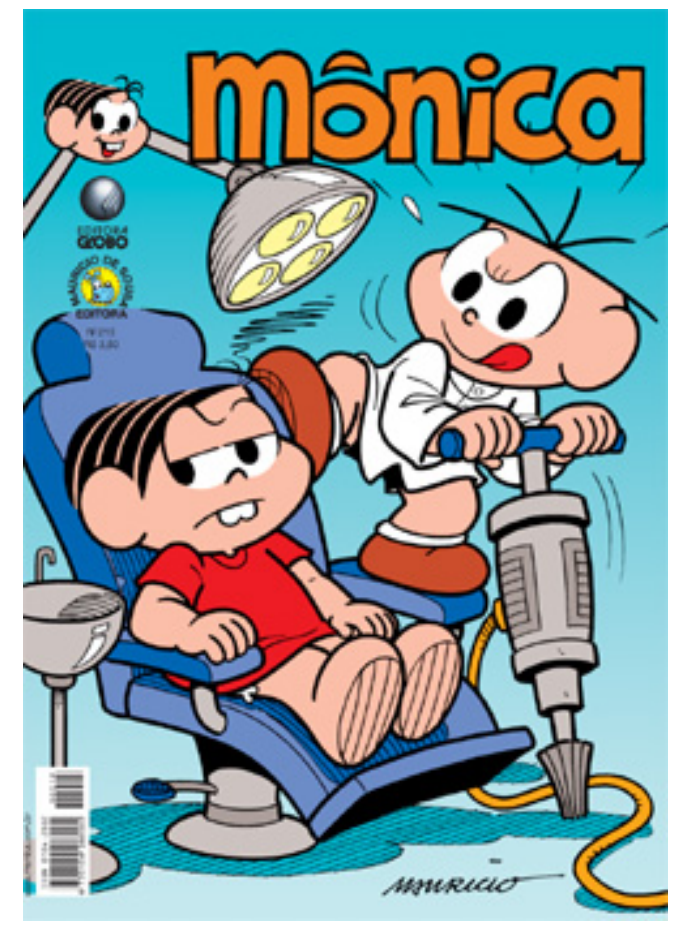


Figura 12

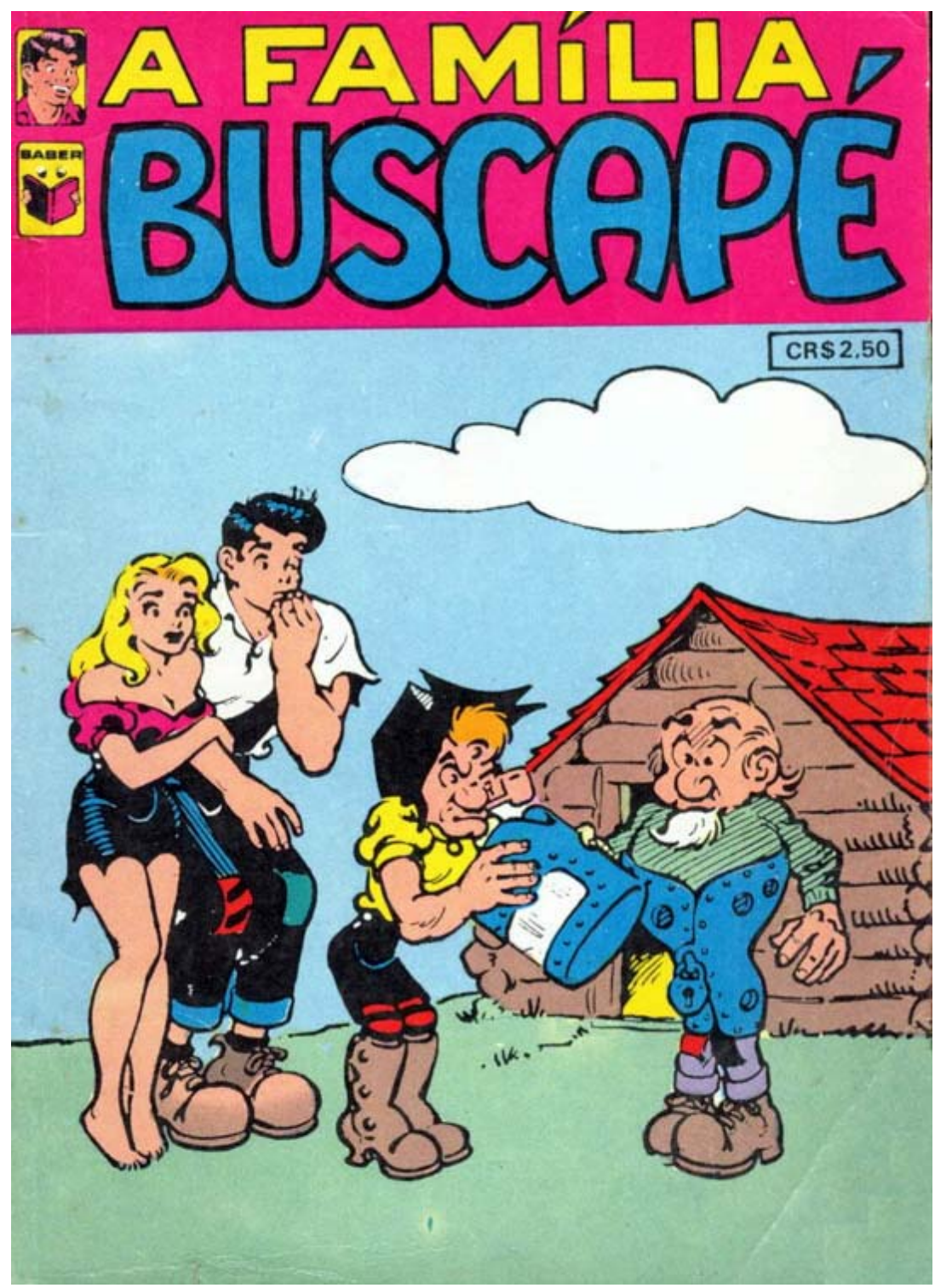


Figura 13
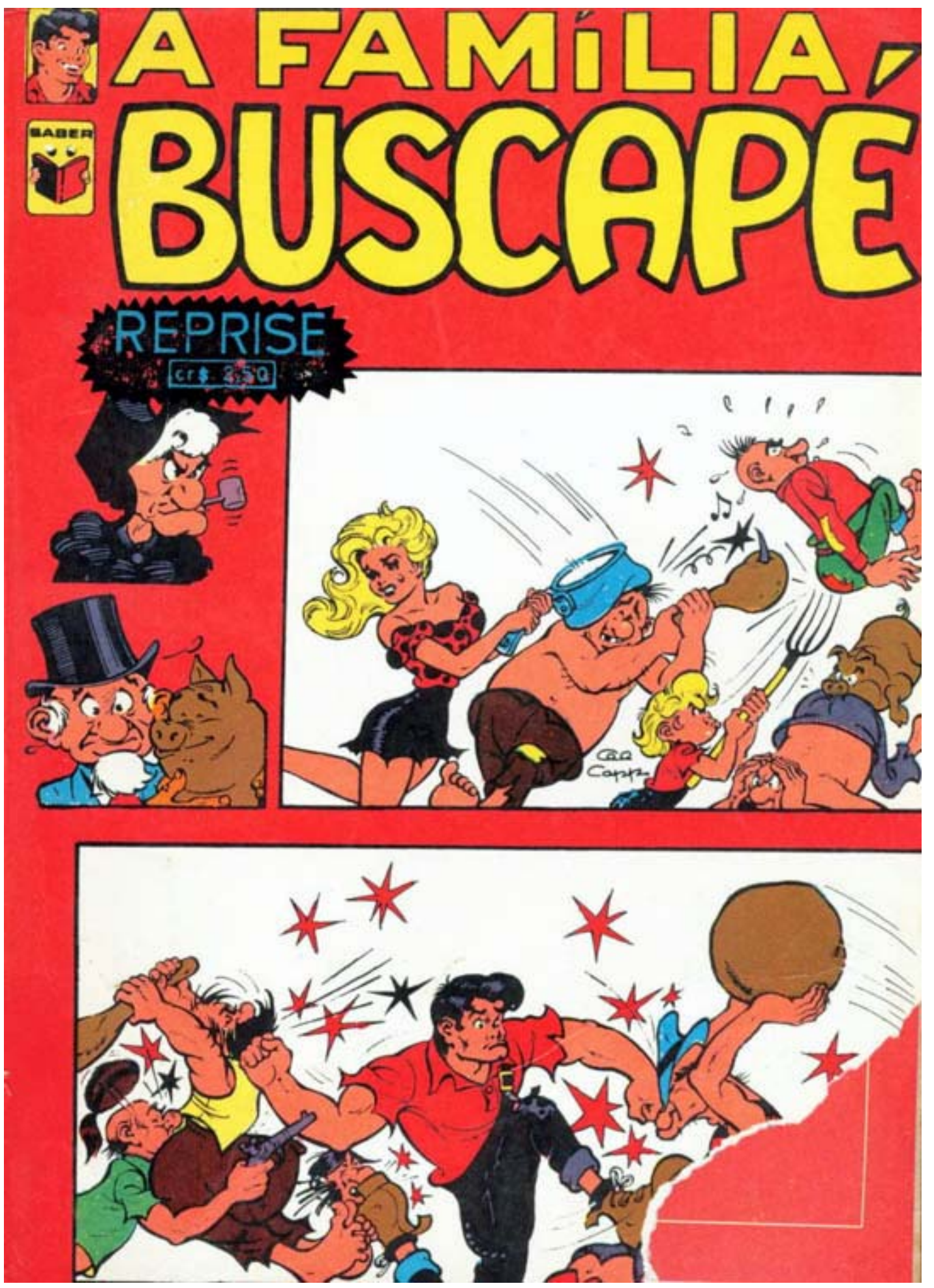
Figura 14

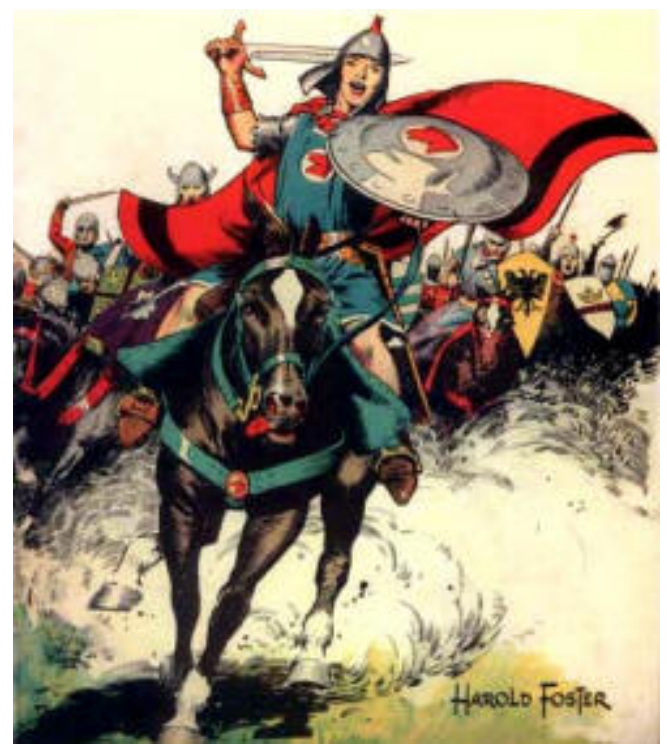


Figura 15

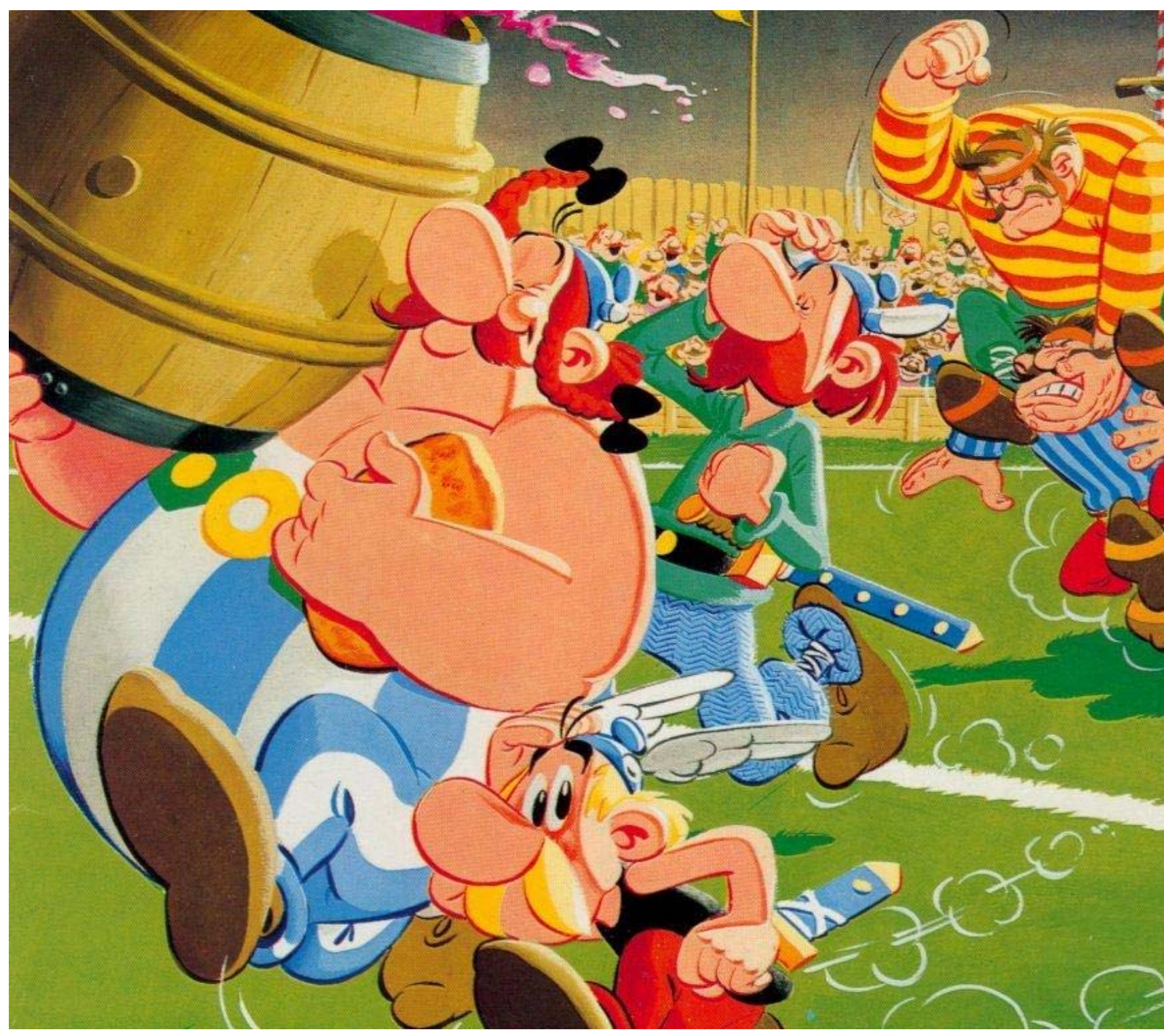

